\title{
$\mathrm{RFID}$ 를 이용한 다차원 특정 객체 추적 시스템의 구현 \\ 민소연 ${ }^{*}$, 정용훈 ${ }^{2}$ \\ ${ }^{1}$ 서일대학 정보통신과, ${ }^{2}$ 숭실대학교 컴퓨터공학과
}

\section{Implementation of Multidimensional Trace System for Specific Object by RFID}

\author{
So-Yeon Min $^{1^{*}}$ and Yong-Hoon Jung ${ }^{2}$ \\ ${ }^{1}$ Dept. of Information and Communication Engr., Seoil University \\ ${ }^{2}$ Dept. of Computer Science, Soongsil University
}

\begin{abstract}
요 약 본 논문에서는 RFID를 이용한 위치 추적 시스템을 제안하고자 한다. 수동형 RFID 태그를 사용자의 신분증 에 삽입하여 위치추적 및 출입인증에 사용한다. 리더는 주기적으로 신호를 브로드캐스팅 하며, 리더는 태그의 응답 신호를 받아 사용자의 위치를 파악할 수 있다. 위치추적 방법으로는 신호의 세기에 따라 이동 경로를 파악할 수 있으 며, 오래 머문 곳에 대한 위치를 이용하여 관심 분야 파악이 가능하다. 또한 백앤드 서버에 저장된 태그 ID값을 이용 하여 보안구역 내 출입인증 시스템으로 활용이 가능하다.
\end{abstract}

\begin{abstract}
This paper suggests that location tracking system by RFID. It uses the location tracking and the authentication to entrance after inserts passive RFID tag into user Identification card. The readers periodically broadcast their signal, and then the readers understand where users are by analyzing them. In one of tracking systems, it is possible to detect the area where user had stayed for the longest time during moving according to signal power, to know user moved path and user next moving path. Also, it can be used in entrance authentication system in security area by using tag ID value which stored to backend server.
\end{abstract}

Key Words : RFID, Multidimensional Trace System, Specific Object

\section{1. 서론}

오늘날 정보통신 및 교통수단의 발달로 공간적 이동과 정보 교환이 급속히 빨라졌을 뿐만 아니라 언제 어디서 나 원하는 정보를 실시간으로 주고받을 수 있는 유비쿼 터스 환경으로 발전하고 있다. 이에 따라 유비쿼터스 컴 퓨팅에 대한 RFID(Radio Frequency Identification) 시스 템이 주목 받고 있다.

RFID 시스템은 무선 주파수를 이용한 자동 인식 기술 로서 물리적 접촉 없이 태그가 부착된 개체의 정보를 읽 거나 기록할 수 있는 시스템으로서 제품 및 자산 관리, 운송 환경 관리, 화물 및 컨테이너 추적, 차량 접근 및 제 어, 전자 문서 관리, 신원 확인, 관광, 교통, 위치 정보는
물론 사람과 동물의 이동 경로 추적 등에까지 폭 넓게 사 용되어지고 있다.

자동항법장치 및 이동통신망 기반의 다양한 위치추적 기술은 유비쿼터스 사회의 특징인 "보이지 않는 기술"을 구현하는 핵심 기술에 해당된다. 이에 따라 다양한 통신 방식을 이용한 위치추적 기술이 연구되고 있으며 위치기 반 서비스는 이미 일상생활에 반드시 필요한 기술로 자 리매김하고 있다. 그러나 광역 위치추적 기술은 위치추정 의 정확도가 낮으며, 실내 및 음영지역에서는 사용하는데 있어 많은 어려움이 있다.

최근에는 이러한 문제점을 해결하고자 Wi-Fi, Zigbee, UWB(Ultra Wide Band), Bluetooth, RFID, 초음파 (Ultrasonic), IrDA 등과 같은 근거리 통신을 이용한 실내

본 논문은 2008년도 서일대학 학술연구비에 의해 연구되었습니다.

*교신저자 : 민소연(symin@seoil.ac.kr)

접수일 09년 11월 13일수정일 (1차 09년 12월 03일, 2차 09년 12월 11일)

게재확정일 09년 12월 16일 
및 근거리 위치추적에 많은 관심이 집중되고 있다. RFID 는 크게 태그와 리더로 분류되며 리더는 다시 송신기 (transmitter)와 수신기(receiver/decoder)로 구성된다. 리더 는 내부의 송신기가 activation 신호를 송출하면 리더와 인접한 태그는 자신에게 할당된 고유 ID값을 회신하게 된다. 리더는 이를 읽어 어떠한 태그들이 자신의 주변에 있는지 판단할 수 있으며, 리더가 인지할 수 있는 감지거 리는 태그의 주파수 세기에 따라 달라질 수 있다.

따라서 본 논문에서는 유비쿼터스 컴퓨팅 기술을 이용 한 위치추적 기술로 RFID를 이용하여 근거리 위치추적 기술을 제안하였다.

\section{2. 관련연구}

\section{1 위치기반 서비스}

위치기반 서비스(LBS : Location Based Service)는 이 동통신망을 기반으로 사람이나 사물의 위치를 정확하게 파악하고 이를 활용하는 응용시스템을 말한다. $3 \mathrm{GPR}(3 \mathrm{rd}$ Generation Partner ship Project)의 TS 22.071에서는 위치 서비스는 "위치기반의 응용 제공이 가능한 네트워크를 이용한 표준화된 서비스”라고 정의하며, OGC(Open GIS Consortium)에서는 "위치기반 서비스를 위치정보의 접속, 제공 또는 위치정보에 의해 작용하는 모든 응용 소프트 웨어 서비스이다"라고 정의한다. 이처럼 유선 및 무선 이 동통신환경에서 휴대폰, $\mathrm{PDA}$ 등의 다양한 이동 컴퓨팅 기기를 사용하여 사용자에게 위치를 기반으로 하는 정보 를 제공하는 서비스라고 정의하여 볼 수 있다. 이러한 서 비스의 사용 예를 들자면, 무선 스마트폰 사용자에게 그 사람이 여행하고 있는 지역에 관한 특별한 광고 제공이 이에 해당된다. LBS는 어떤 네트워크 사용자가 현재 위 치하고 있는 위치 정보를 알아내기 위해 여러 기술들을 활용하며, 첫 번째로 미국 국방부를 위해 개발된 24개의 나브스타 위성들을 이용한 GPS를 사용 예로 들 수 가 있 다. 이 위성들을 이용하면 지상 $50 \sim 100 \mathrm{~m}$ 내의 범위에 있는 GPS 수신기의 위치를 알아낼 수 있으며 LBS를 이 용하려면 각각의 사용자는 GPS 수신기를 내장한 휴대장 치를 가지고 있어야 한다. 두 번째 사용 예로는 E911을 들 수가 있고, 긴급 구조대 파견을 위해 전화 서비스 회 사가 발신자의 전화번호를 정확하게 알아낼 수 있는 서 비스로서 $\mathrm{FCC}$ 가 처음 주도하였다. E911은 미국에서 가 장 광범위하게 사용되는 $\mathrm{LBS}$ 의 사용 예이고 향후 전화 서비스 회사들에 의해 무선전화의 현재 통화 위치를 제 공할 수가 있게 될 것이다.

\subsection{WLAN}

WLAN(Wireless LAN)을 이용한 방식에서는 단말이 수신하는 RF 신호 강도에 의한 신호 감쇠 측정을 통해 신호 전달 거리를 측정하여 위치를 계산할 수 있다. 이를 이용한 대표적인 시스템으로는 마이크로소프트사에서 개 발한 RADAR 시스템, Ekahau, Intel의 Place Lab 등이 있 다[1 3]. 이 중 Ekahau는 크게 manager, server, client로 구성되며 manager는 실내 WLAN 신호를 수집하고 측위 모델을 구성하는 역할을 수행한다. 서버는 PDA, PC, handset 등 WLAN 인터페이스 기능을 가진 client가 위치 를 요청하면 manager가 측정한 측위 모델에 근거하여 위 치를 계산하여 회신한다. Ekahau의 측위 정확도는 일반 적으로 1 3m로 알려져 있으며, manager에 의하여 지도 상의 많은 지점에서 측정치를 수집할수록 서버의 정확도 가 증가한다. Intel의 Place Lab은 알려진 지점에서 신호 를 수집하여 측위모델을 구성하여 클라이언트에게 서비 스하는 점에서는 Ekahau와 유사하다. 반면 Ekahau는 지 도상에서 알려진 지점을 표시하고 이로부터 fingerprint 데이터베이스를 구성하는 반면 Place Lab은 GPS/WLAN 이 동시에 설치된 이동기기를 활용하여 3 차원 좌표를 GPS로부터 얻은 다음에 이를 활용하여 구성한다.

\subsection{RFID 기반 측위 기술}

$\mathrm{RFID}$ 리더가 인지할 수 있는 감지거리는 약 $2.5 \mathrm{~m}$ 정 도이므로 특정한 위치에 대한 proximity 위치 센서로 활 용 가능하며, 한정된 실내 공간에 균등하게 배치할 경우 측위 시스템으로도 활용 가능하다. 이를 이용한 대표적인 시스템의 예로는 SpotON을 들 수가 있다[4]. SpotON은 대상이 되는 태그에 대하여 각 노드에서 수집된 신호세 기 데이터에 군집 알고리즘(aggregation algorithm)을 적 용하여 위치를 계산한다. 또한 Kantor와 Singh는 RFID 신호를 TOA(Time of Arrival)와 같이 활용하여 거리를 측정하는 방법을 발표하였으며[5], 미국 NIST의 실내 환 경에서 ad-hoc 무선 네트워크 환경에서 안정적으로 responder를 추적하는 문제의 가능성을 조사하고 있다.

\section{4 구현 방식에 따른 무선 위치추적 기술}

무선 통신 기술을 사용한 위치정보 서비스는 무선 통 신 기술의 종류와 무관하게 Cell-ID 방식, 삼각법에 의한 방식, 확률론적 모델링에 근거한 방식, 화면 분석 등 다양 한 방법을 통해 구현될 수 있다.

\subsubsection{Cell-ID 방식}

Proximity 방식이라고도 불리는 Cell-ID 방식은 가장 
단순한 형태의 위치 추적 방법이다. 즉 추적하고자하는 이동 개체가 셀이라 불리는 기 지정된 공간에 존재하는 지의 여부를 통해 이동 개체의 위치를 확인해 주는 방법 이다. 따라서 셀의 크기가 작고 촘촘하게 배치되어 있을 수록 위치 추정의 정확도는 높아진다.

이 방식은 이동통신망, RFID, 무선랜 등 다양한 기술 을 이용해서 구현 가능하다. 이동통신망 기술을 사용하는 경우 셀 반경이 수 백 $\mathrm{m}$ 에서 수 $\mathrm{Km}$ 에 달하기 때문에 위 치 추정의 오차율 또한 수 백 $\mathrm{m}$ 에서 수 천m에 달하게 된 다. 반면에, $\mathrm{ZigBee}$ 나 UWB와 같은 초단거리 위치추정 기술을 사용하는 경우 주로 셀의 반경을 $3 \sim 5 \mathrm{~m}$ 정도로 작 게 만들기 때문에 오차 범위는 최대 수 미터이내가 된다. 이 방식은 특정 셀에 이동 개체가 존재하는지의 여부만 을 확인하기 때문에 간단히 구현할 수 있고 구축비용도 줄일 수 있다. 그러나 셀의 밀도가 높아질수록 구현의 난 이도가 높아지고 구축 및 관리 비용도 커지며 구축 가능 한 환경이 제약된다는 단점이 있다. Cell-ID 방식에서는 이동 개체가 두 개 이상의 셀 경계에 존재하는 경우 셀 선택의 문제가 발생하며 이에 따라 오차율이 크게 달라 질 수 있다. 이 방식은 넓은 공간을 격자화하여 모든 대 상 공간에 적용하는 것도 가능하지만 이동 경로와 같이 관심의 대상이 되는 주요 지점만을 골라서 이동 개체의 존재 여부를 확인하는 경우 적합하다.

\subsection{2 삼각법}

삼각법(Triangulation)은 가장 보편적인 위치추적 방법 으로 세 개의 기준점으로부터 이동 개체까지의 거리를 알아냄으로써 실제 이동 개체가 있는 위치를 추정하는 방법이다. 이를 위해서는 세 개의 기준점에 대한 정보를 사전에 정확히 알아야 한다.

삼각법에서 이동 개체와 세 개의 기준점 사이의 거리 를 알아내는 방법에는 여러 가지 방법이 있다. 이동 개체 혹은 기준점이 수신하는 전파의 세기(RSS:Received Signal Strength), 전파 도착 시간(TOA:Time of Arrival), 전파 도착 시간차(TDOA:Time Difference of Arrival), 캐 리어 신호 위상(POA:carrier signal Phase of Arrival), 그 리고 전파의 도착각도(AOA:Angle of Arrival)와 같은 정 보를 이용하여 이동 개체와 기준점 사이의 거리를 계산 한다.

$\mathrm{RSS}$ 를 이용하여 거리를 구하는 경우에 있어서, 신호 의 세기와 거리 사이의 관계를 나타내는 Friis의 공식을 이용하며[6,7], TOA를 이용하는 경우 $($ 거리 $)=($ 전파의 속 도)×(이동 시간)과 같은 간단한 물리 공식을 이용한다. 일 반적으로 실내 환경에서는 $\mathrm{AOA}, \mathrm{POA}$ 는 정확히 측정하 기가 어렵기 때문에 무선랜 기술 기반의 근거리 위치 추
정 시스템에서는 주로 RSS나 TOA를 이용하고 있다[8,9]. 이 방식은 시스템이 구축되는 곳의 전파 환경에 의해 시 스템의 성능이 좌우되며, 이동 개체와 기준점 사이에 존 재하는 장애물 혹은 반사, 굴절 등을 대표적인 요인으로 볼 수 있다. 이러한 문제를 해결하기 위해, 기준점의 개수 를 4 개 이상으로 하거나 수신 전파 세기와 전파 도착 시 간 혹은 수신 전파 세기와 전파 도착 각도와 같이 두 가 지 이상의 거리 측정 방법을 병행함으로써 오차율을 줄 일 수 있다. 또한 동시에 여러 개의 기준점에서 수신한 정보를 바탕으로 현재 위치를 추적하기 때문에 여러 기 준점 사이에 동기를 맞추는 것이 중요하다.

\section{3. 제안하는 시스템}

본 연구에서 제안하는 시스템은 RFID 시스템의 태그 와 리더를 이용하여 인증과 위치추적을 한다. 먼저 리더 에서 태그의 데이터를 읽어 들여 데이터베이스 내에 있 는 정보와 동일한지를 비교하는 과정을 통해 태그 사용 자를 인증한다. 인증에 성공한 사용자는 보안구역 내에 출입이 허용되며, 위치추적 시스템에서는 사용자의 위치 추적을 시작 하게 된다. 제안하는 시스템 구조를 그림 1 에서 나타내었으며, 출입이 허가된 사용자가 보안구역 내 에서 이동할 경우 해당 리더는 주기적으로 신호를 브로 드캐스팅하여 그 신호에 응답하는 태그의 정보를 읽어 위치를 추적하게 된다.

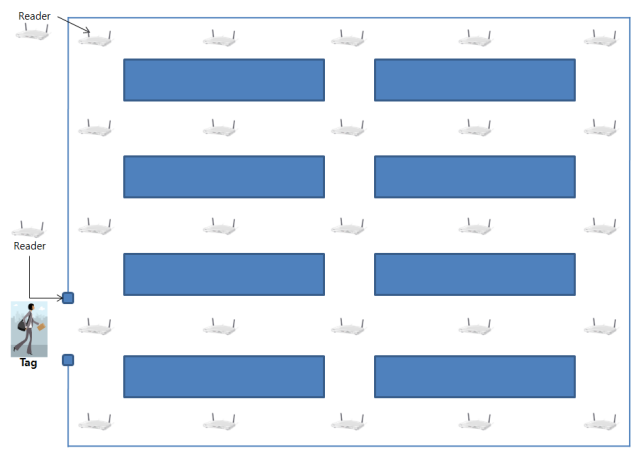

[그림 1] 제안하는 시스템

\subsection{RIFD 태그}

태그는 능동형 태그와 수동형 태그로 나눠진다. 제안 하는 시스템에서는 수동형 태그를 사용하여 사용자의 신 분증에 삽입하여 사용한다. 태그는 사용자의 신분을 증명 할 수 있는 역할과 특정 구역에서 사용자의 위치를 파악 
하기 위해 사용되며, 신분증에 삽입된 태그에는 사용자를 식별할 수 있는 고유한 UID(User Identification) 값을 부 여하고 이를 이용하여 리더는 사용자를 인증하고 위치를 추적하게 된다. 또한 태그는 리더가 일정한 주기로 전송 하는 신호에 응답 메시지로 자신의 UID 값을 전송하게 된다.

\subsection{RFID 리더}

리더는 주기적으로 쿼리를 브로드캐스팅 한다. 이렇게 브로드캐스팅된 신호의 응답으로 태그는 자신의 UID 값 을 리더에 보내고, 리더는 이 신호를 백앤드서버로 보내 어 등록된 태그인지 확인하며, 등록된 태그일 경우 위치 추적시스템을 이용하여 위치 추적을 시작한다.

태그를 추적하는 방법으로는 리더가 보낸 쿼리에 태그 의 응답 메시지 신호의 세기를 이용하여 위치를 파악할 수 있다. 또한 태그의 신호세기 분포를 이용하여 어느 곳 에 오래 머물렀는지 파악할 수 있다.

\section{3 백앤드서버}

리더로부터 전송된 태그 UID 값을 등록 관리하며, 태 그의 UID 값 이외에도 사용자 인증에 필요한 사용자의 정보 등을 등록 관리한다.

리더에서 전송되는 태그 UID 값을 데이터베이스 내에 있는 정보와 비교하여 일치하는 정보가 있을 경우 허가 메시지를 리더에게 전송하며, 일치하는 정보가 없을 경우 거부 메시지를 리더에게 전송한다.

\section{4 위치추적시스템}

위치추적시스템은 위치를 추적하는 대상이 되는 태그 와 리더 그리고 위치계산시스템으로 구성되며 태그는 1 차적으로 인증된 태그만을 추적하게 된다. 허가된 사용자 가 특정 구역 내에 출입했을 경우 리더가 송출한 쿼리 신 호를 수신한 태그는 리더에게 자신의 UID 값을 전송한 다.

신분증을 이용하여 보안 구역 내에서 태그를 통해 전 파가 송출되고 보안 구역 내의 주요위치에 설치된 리더 (내장형 e-POP, 환경센서)가 인식하고 전파세기를 필터 링한 후 위치추적시스템으로 이를 전달하며 위치추적엔 진은 실시간으로 해당 사용자의 위치를 파악한다. 식(1) 은 $\mathrm{u}$ 개의 신분증, $\mathrm{m}$ 개의 reference 태그와 $\mathrm{n}$ 개의 RFID 무 선송수신기를 사용하여 작성하였으며 신분증의 RF 전파 강도 벡터를 표현하고 있다.

$$
P=\left(P_{1}, P_{2}, \ldots, P_{n}\right)
$$

(단, $\mathrm{P}_{\mathrm{i}}$ 가 1 개의 RFID 무선송수신기로부터 받은 신호 의강도를 나타냄 : $\mathrm{i} \in(1, \mathrm{n})$ 인 경우)

reference 태그의 전파강도 벡터는 식(2)와 같이 나타 낼 수 있다.

$$
Q=\left(Q_{1}, Q_{2}, \ldots, Q_{n}\right)
$$

(단, $\mathrm{Q}_{\mathrm{i}}$ 가 1 개의 RFID 무선송수신기로부터 받은 신호 의 강도를 나타냄 : $\mathrm{i} \in(1, \mathrm{n})$ 인 경우)

리더는 태그로부터 수신한 UID 값을 백앤드서버에 전 송하여 허가된 사용자인지 확인하여, 허가된 사용자일 경 우에만 위치추적을 시작한다. 또한, 리더는 주기적으로 쿼리 신호를 송출하여 태그로부터 응답메시지를 요구하 고, 태그의 신호세기를 이용하여 위치를 계산하게 된다. 전파강도를 이용한 신분증과 reference 태그의 Euclidean 거리는 식(3)과 같이 표현된다.

$$
E_{j}=\sqrt{\sum_{i=1}^{n}\left(P_{i}-Q_{i}\right)^{2}}
$$

(단, 신분증 $\mathrm{a}$ 에 대해 $\mathrm{a} \in(1, \mathrm{u})$ 경우)

위의 식(1), (2), (3)을 이용하여 신분증의 위치 좌표 $(\mathrm{x}, \mathrm{y})$ 를 식(4)와 같이 구할 수 있다. 태그의 신호를 수신한 리더기들 중에 가장 신호의 세기가 큰 리더를 그 태그의 위치와 근접한 리더로 인식하여 태그의 위치를 알 수 있 다.

$$
(x, y)=\sum_{i=1}^{k} W_{i}\left(x_{i}-y_{i}\right)
$$

또한 각 리더에서 태그의 신호를 수신하여 하나의 리 더에 지속적으로 신호의 세기가 클 경우 한 곳에 오래 머 물렀다는 것을 알 수 있다. 이렇게 신호세기를 이용하여 사용자가 오래 머문 곳을 알 수 있으며, 색상 분포를 이 용하여 관심 분야를 알 수 있다. 그림 2는 리더가 태그의 위치 추적 및 인증을 하는 흐름을 나타내고 있다. 즉, 사 용자는 자신이 소지한 신분증으로 인증 단계를 거치게 되며, 이 과정에서 사용자의 신분증에 삽입되어 있는 태 그의 UID 값을 이용하게 된다. 리더는 주기적으로 신호 를 브로드캐스팅 하고 태그는 UID 값을 리더에게 전송하 며 리더는 태그의 UID 값을 백앤드서버에 보내어 태그를 인증 확인 후 다시 리더에게 태그 정보를 보낸다. 리더는 정당한 태그 정보일 경우 위치추적시스템에게 추적 요청 
을 하게 되고, 위치추적시스템은 주기적인 태그의 신호를 이용하여 위치를 추적한다.

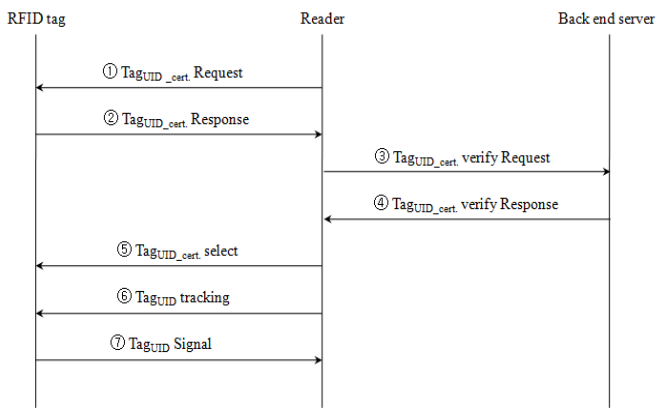

[그림 2] 위치추적 시스템 흐름도

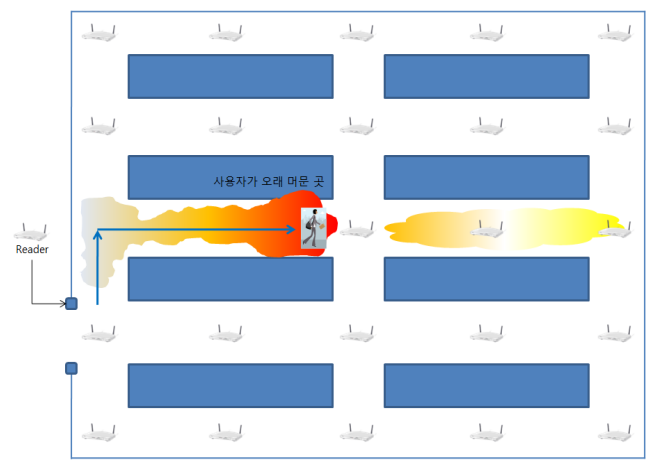

[그림 3] 위치추적 시스템

그림 3은 사용자가 전자신분증을 가지고 특정 구역 내 에 출입하여 추적한 결과를 나타내고 붉게 표시된 부분 은 사용자가 이동 중 오래 머문 곳을 의미한다. 오래 머 물렀다는 것은 그곳에 있는 문서나 책 또는 그 분야에 관 심이 있다는 것을 알 수 있다.

\section{4. 성능평가}

사용자의 이동속도에 따른 위치인식 및 동선을 분석하 기 위하여 사용자가 소지하는 태그의 위치 검출 실험을 하였다. 실험을 위해서는 $13.56 \mathrm{MHz}$ 주파수를 사용하는 교육용 키트를 사용 하였으며, 이때 태그와 리더기의 인 식거리는 약 $30 \mathrm{~cm}$ 정도로 짧은 인식거리를 가지고 있다. 또한 태그를 신분증으로 가정하여 태그를 이동시켜 위치 검출을 실험하였으며, 리더는 구역 내에 고정시켜 태그의 데이터를 취합 할 수 있도록 구성하였다. 그리고 에이전 트 서버를 이용하여 데이터베이스에 시간과 위치, 태그
데이터를 저장하도록 하여 수회 반복하여 실험 하였다. 위치검출을 위해 태그에서 전송되는 데이터는 리더를 통 하여 에이전트 서버에 데이터를 전송하고 위치추적 엔진 과 환경 분석 엔진에 각각 필요한 데이터를 보내주게 된 다. 이때 에이전트 서버는 데이터베이스에 저장 할 수 있도록 데이터를 변환하여 전송하게 된다.

첫 번째, 이동속도 변화에 따른 인식 실험을 위해 이동 속도를 '느리게', ‘중간', ‘빠르게'의 3 개의 항목을 가지고 실시하였으며, 직선거리에 $2 \mathrm{~m}$ 마다 리더기를 설치하였고 중간에 어느 곳에 머무르지 않았다는 가정 하에 실험하 였다. 그림 4 에서 이동속도 변화에 따른 인식 실험에 사 용한 구성도를 나타내고 있다.

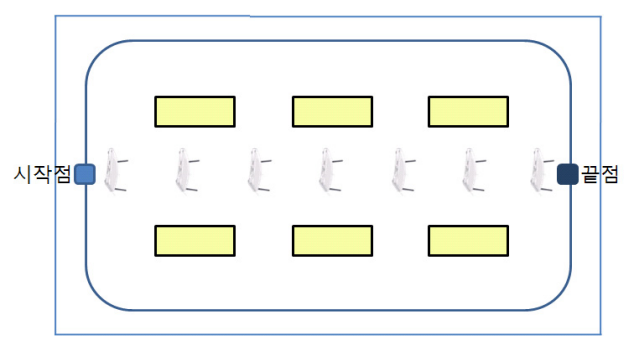

[그림 4] 이동속도 실험에 사용한 구성도

[표 1] 이동속도 실험

\begin{tabular}{|c|c|c|c|c|}
\hline \multirow{2}{*}{$\begin{array}{l}\text { 항목 } \\
\text { 순번 }\end{array}$} & \multirow[b]{2}{*}{$\begin{array}{l}\text { 이동 } \\
\text { 속도 }\end{array}$} & \multirow{2}{*}{$\begin{array}{l}\text { 이동 } \\
\text { 거리 }\end{array}$} & \multicolumn{2}{|c|}{ 태그 인식 } \\
\hline & & & $\begin{array}{c}\text { 성공률 } \\
(\%)\end{array}$ & $\begin{array}{c}\text { 실패률 } \\
(\%)\end{array}$ \\
\hline 1 & \multirow{3}{*}{$\begin{array}{c}\text { 느리게 } \\
\text { (21초 이상) }\end{array}$} & \multirow{3}{*}{$15 \mathrm{~m}$} & 100 & 0 \\
\hline 2 & & & 100 & 0 \\
\hline 3 & & & 100 & 0 \\
\hline 1 & \multirow{3}{*}{$\begin{array}{c}\text { 중간 } \\
\text { (17 20초) }\end{array}$} & \multirow{3}{*}{$15 \mathrm{~m}$} & 100 & 0 \\
\hline 2 & & & 99 & 1 \\
\hline 3 & & & 99 & 1 \\
\hline 1 & \multirow{3}{*}{$\begin{array}{c}\text { 빠르게 } \\
\text { (16초 이하) }\end{array}$} & \multirow{3}{*}{$15 \mathrm{~m}$} & 98 & 2 \\
\hline 2 & & & 96 & 4 \\
\hline 3 & & & 97 & 3 \\
\hline
\end{tabular}

각 항목은 일반인이 걷는 평균속도를 $0 \sim 15 \mathrm{~m}$ 지점을 통과하는데 걸리는 시간을 약 17 20초를 '중간'으로 보 고 이보다 늦게 걸을 경우 약 21 초 이상을 '느리게', 약 16초 이하를 ‘빠르게’로 구분하여 테스트 하였다.

이동거리는 위치검출 시작지점부터 끝 지점까지의 총 거리를 나타내며, 실험을 위해 총 처음시작지점부터 끝 지점까지 이동을 총 100 회씩 3차례에 걸쳐 실험 하였다. 표 1에서 나타내었듯이 $1 \sim 3$ 회의 인식 실패률은 빠르게 이동하였을 경우 대부분 발생하였고, 이와 같은 원인은 태그 데이터를 리더에서 취합하는 과정에서 현재 리더의 
위치와 다음 위치에 설치된 리더에서 인식이 모두 되는 경우(신호의 세기를 구분하여 가장 작은 신호를 먼저 읽 는 쪽에 인식하도록 함), 리더의 주기적 수신 속도(0.3 초 1초 사이)와 실험하는 사람의 이동속도 차가 존재하 기 때문에 현재위치에서 검출되기보다 다음 위치에서 검 출이 먼저 된 경우로 분석되어진다. 사용자가 한 곳에 오 래 머무른 것에 대한 실험 평가는 교육용 키트를 이용한 실험을 통해 실제 확인은 할 수 없었지만, 기존 연구에서 신호의 세기를 이용하여 태그가 오래 머물러 있는 곳을 파악할 수 있음을 알 수 있다.

두 번째 실험에서는 RFID 리더기의 수와 위치를 변화 시켜가며 7 가지 경로를 선택하여 위치추적 성공여부에 대한 실험을 수행하였다.

그림 5에서는 RFID 리더 대수별 위치구성을 나타내고 있고 있으며, 그림 6 에서는 위치추적 실험을 위해 선택한 대표 경로를 나타내고 있다. 7 개 경로를 선택하여 RFID 리더기 수와 위치를 변화시켜 실험한 위치 추적 결과를 표 2에서 나타내었다.

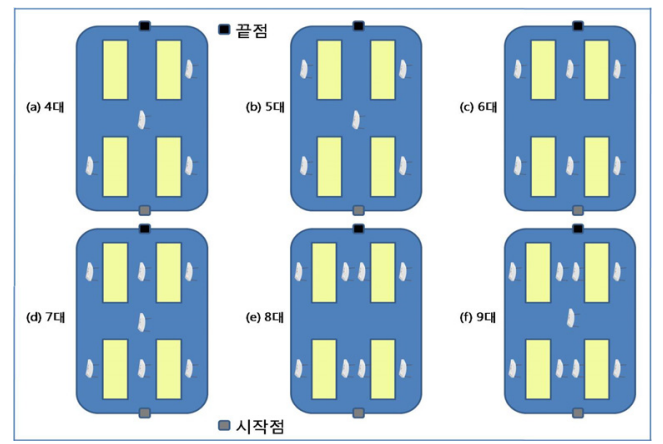

[그림 5] RFID 리더기 수 변화에 따른 구성도

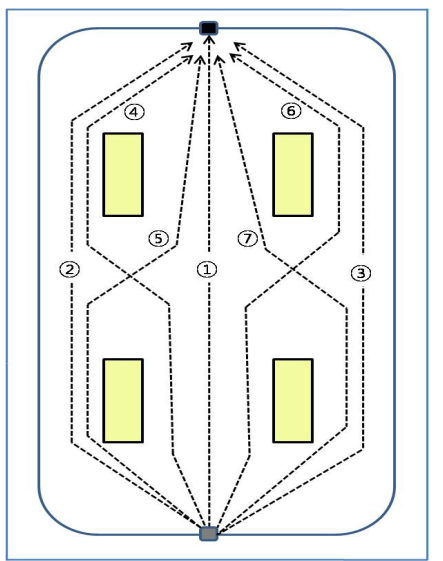

[그림 6] 위치추적 실험을 위한 선택경로
[표 2] 리더기 수별 위치추적 결과

\begin{tabular}{|c|c|c|}
\hline \multirow{2}{*}{$\begin{array}{c}\text { 리더기 } \\
\text { 개수 }\end{array}$} & \multicolumn{2}{|c|}{ 위치추적 } \\
\cline { 2 - 3 } & 성공(\%) & 실패(\%) \\
\hline 4 & 34 & 66 \\
\hline 5 & 67 & 33 \\
\hline 6 & 69 & 31 \\
\hline 7 & 73 & 27 \\
\hline 8 & 100 & 0 \\
\hline 9 & 100 & 0 \\
\hline 10 & 100 & 0 \\
\hline
\end{tabular}

도서관 서고의 시작지점과 끝지점에 각각 리더기를 설 치하고 다양한 위치의 중간지점마다 위치 추적을 위한 리더기 설치대수를 변화해가며 미리 정해둔 동선을 파악 할 수 있는지를 실험하였다. 실험결과 8 개 이상의 리더기 가 있어야 위치 추적을 할 수 있으며, 최소 5 개의 리더기 가 있으면 추적의 오류를 줄일 수 있었다. 위치추적의 성 공은 리더기에서 실험자가 책장의 어느 위치에 있는지를 판단할 수 있음을 말하고 되돌아오는 것도 포함하고 있다.

세 번째 실험에서는 오래 머문 곳에 대한 위치를 이용 하여 관심 분야를 파악하는 실험을 실시하였다. RFID 리 더는 태그가 보내온 신호를 한번만 읽은 것이 아니라 여 러 번 읽는다. RFID로 첫 번째 신호가 입력된 시간과 마 지막으로 입력된 신호의 시간차를 계산하여 영역별 머문 시간을 계산할 수 있지만 본 실험에서는 교육용 키트를 사용하였기 때문에 다음과 같은 실험을 수행하였다. 즉, 첫 번째 RFID 리더에서 읽은 신호와 두 번째 RFID 리더 에서 읽은 신호간의 시간차를 첫 번째 영역에 머문 시간 으로 계산하여 관심분야에 대한 정도를 측정하였다. 도서 관 서고에서 일어나는 실제상황의 경우는 관심 있는 책 을 꺼내서 읽고, 이동하고 하는 시간이 랜덤 하겠지만, 실 험을 위해 영역별로 머문 시간의 길이를 의도적으로 설 정하여 관심분야 측정에 대한 실험을 실시하였다. 그림 7 은 실험을 위해 설치한 RFID 리더 배치를 나타내고 그림 8 은 임의적으로 선택한 이동경로를 나타내고 있다.

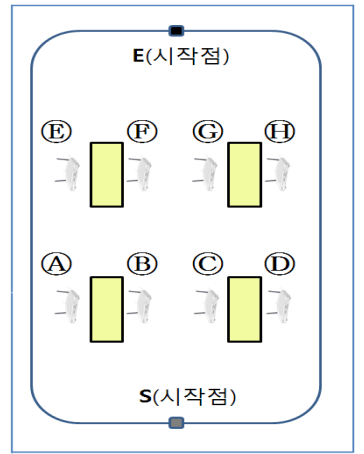

[그림 7] 관심분야 측정을 위한 구성도 


\begin{tabular}{|c|c|}
\hline 구분 & 이동경로 \\
\hline 가 & $S \rightarrow(A) \rightarrow(F) \rightarrow E$ \\
\hline 나 & $\mathrm{S} \rightarrow$ (D) $\rightarrow$ (F) $\rightarrow$ (G) $\rightarrow E$ \\
\hline 다 & $\mathrm{S} \rightarrow$ (B) $\rightarrow(\mathrm{C}) \rightarrow(\mathbb{1 1}) \rightarrow \mathrm{E}$ \\
\hline 라 & $\mathrm{S} \rightarrow$ (B) $\rightarrow(\mathrm{C}) \rightarrow(\mathrm{D}) \rightarrow(\mathrm{H}) \rightarrow(\mathrm{G}) \rightarrow \mathrm{E}$ \\
\hline 마 & $\mathrm{S} \rightarrow$ (B) $\rightarrow$ (A) $\rightarrow$ (E) $\rightarrow$ (F) $\rightarrow$ (G) $\rightarrow$ (H) $\rightarrow \mathrm{E}$ \\
\hline
\end{tabular}

[그림 8] 관심분야 측정을 위한 이동경로

[표 3] 관심분야 측정 실험 결과

\begin{tabular}{|c|c|c|c|c|c|}
\hline \multirow{2}{*}{ 경로 } & \multicolumn{2}{|c}{ 각 영역별 머문 시간 } & \multicolumn{2}{c|}{ 단위:[sec] } \\
\cline { 2 - 6 } & 가 & 나 & 다 & 라 & 마 \\
\hline (A) & 10 & - & - & - & 11 \\
\hline (B) & - & - & 20 & 5 & 7 \\
\hline C & - & - & 9 & 7 & - \\
\hline (D) & - & 15 & - & 33 & - \\
\hline (E) & - & - & - & - & 41 \\
\hline (F) & 35 & 40 & - & - & 103 \\
\hline (G) & - & 5 & - & 52 & 14 \\
\hline (H) & - & - & 7 & 8 & 8 \\
\hline
\end{tabular}

또한 표 3에서는 그림 7과 그림 8에서 나타낸 다섯 가 지 이동경로에 대해 각 경우에 있어서 관심 분야를 파악 한 결과를 나타내고 있으며, 머무는 시간이 타 영역에 비 해 오래 측정된 곳이 관심도를 갖는 분야라고 판단할 수 있다.

\section{5. 결론}

본 논문에서는 RFID 시스템을 이용하여 사용자 인증 및 추적에 대한 연구를 수행하였다. 첫 번째 실험에서는 사용자의 이동속도 변화에 따른 인식률을 측정하였고, 두 번째 실험에서는 7가지 이동경로와 RFID 리더기 수를 변 화시켜가며 위치추적 결과를 분석하였다. 또한, 세 번째 실험에서는 처음의 RFID 리더에서 읽은 신호와 그 다음 에 위치한 RFID 리더에서 읽은 신호간의 시간차를 처음 영역에 머문 시간으로 계산하여 관심분야에 대한 정도를 측정하였다.

제안하는 시스템에서와 기존 시스템에서는 사용자의
실제 얼굴과 태그 사용자가 동일한 인물인지를 알 수 없 으므로 다른 사용자의 신분증을 이용하여 출입 후 보안 구역 내에 문서 유출이 가능하고 이로 인해 사고가 발생 할 수 있다. 그러므로 향후 연구에서는, 제안하는 시스템 에 생체인식 기능 또는 영상처리 과정 등을 추가하여 인 증과정시의 보안성 강화에 대한 연구가 이루어질 계획이 다.

\section{참고문헌}

[1] P. Bahl and V.N. Padmanabhan, "RADAR: An In-Building RF-Based User Location and Tracking System," In Proc. of IEEE Infocom 2000 Conf. on Computer Commun., Vol.2, Mar. 2000, pp.775-784.

[2] http: //www.ekahau.com

[3] http: //www.placelab.org

[4] J. Hightower, R. Want, and G. Borriello, "Spoton: AnIndoor 3d Location Sensing Technology Based on F Signal Strength," Technical Report 00-02-02, niversity of Washington, 2000.

[5] G. Kantor and S. Singh, "Preliminary Results in Range-Only Localization and Mapping," IEEE Conf. on Robotics and Automation, Washington D.C., May 2002.

[6] T. S. Rappaport, Wireless Communications: Principles and Practice, Prentice Hall, 2nd ed., 2001.

[7] F. Lassabe, P. Canalda, P. Chatonnay, and F. Spies, "A Friss-based Calibrated Model for WiFi Terminals Positioning," Proc. of WoWMoM ' 05, Jun. 2005, pp. 382-387.

[8] M. A. Youssef, A. Agrawala, and A. U. Shankar, "WLAN Location Determination via Clustering and Probability Distribution," IEEE Int'l. Conf. on Pervasive Computing and Communications, Mar.2003, pp. 143-150.

[9] S. Ito and N. Kawaguchi, "Bayesian Based Location Estimation System Using Wireless LAN," IEEE Int'l. Conf. on Pervasive Computing and Communications, Mar. 2003, pp. 273-278. 
민 소 연(So-yeon Min)

[종신회원]

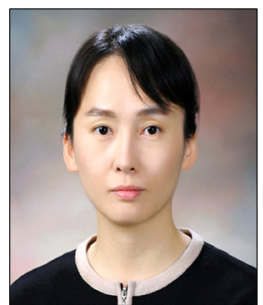

- 1994년 2월 : 숭실대학교 전자공 학과 (공학사)

- 1996년 2월 : 숭실대학교 일반대 학원 전자공학과 (공학석사)

- 2003년 2월 : 숭실대학교 일반대 학원 전자공학과 (공학박사)

- 2005년 3월 현재 : 서일대학 정보통신과 교수

<관심분야>

통신 및 신호처리, 정보통신

정 용 훈(Yong-hoon Jung)

[정회원]

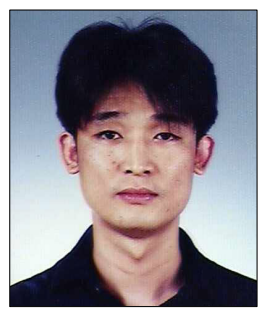

- 2004년 2월 : 숭실대학교 전자계 산원 멀티미디어학과(공학사)

- 2006년 2월 : 숭실대학교 일반대 학원 컴퓨터학과 (공학석사)

- 2006년 3월 현재 : 숭실대학 교 일반대학원 컴퓨터학과 (박사 과정)

<관심분야>

멀티미디어 보안, RFID, DRM 